\title{
Dental Caries : The Most Common Disease Worldwide and Preventive Strategies
}

\author{
Dogan Ozdemir ${ }^{1}$ \\ ${ }^{1}$ Faculty of Dentistry, Basic Sciences, Ishik University, Arbil, Iraq \\ Correspondence: Dogan Ozdemir, Dean of Engineering Faculty, Ishik University, 100 Street, 44, Arbil, KRG, \\ Iraq. Tel: 964-750-636-9587. E-mail: ozdemirtalha@gmail.com
}

Received: September 9, 2013 Accepted: September 17, 2013 Online Published: September 28, 2013

doi:10.5539/ijb.v5n4p55

URL: http://dx.doi.org/10.5539/ijb.v5n4p55

\begin{abstract}
Dental caries is the most prevalent infectious disease worldwide. There are different causes of tooth caries such as the dietary habit and oral hygiene. The morphology of the tooth also plays an important role in the formation of caries. The organic material of the tooth is made up of hydroxyapatite crystals. These crystals are demineralized in the presence of high acidity. The $\mathrm{pH}$ of the mouth environment is critical in the mineralization-demineralization process. It is a well-known fact that when carbohydrate consumed in daily diet with the help of bacteria the sugar is fermented and lactic acid is formed. Consequently the $\mathrm{pH}$ of the environment decreases which will lead the dental caries formation. The porpuse of this review is to give a comprehensive look at dental caries in terms of microbiology, diet, oral hygiene together with professional and social preventive measures.
\end{abstract}

Keywords: dental caries, tooth enamel, oral hygiene, diet and lactic acid

\section{Introduction}

Tooth decay (dental caries) is a significant health problem worldwide. It affects not only the vast majority of adults but also children, from $60 \%$ to $90 \%$ of them. In other words, six to nine children in every 10 are affected by tooth decay (Marinho et al., 2013).

Dental caries is an infective transmittable bacterial disease characterized by a multi factorial pathology (Xhemnica et al., 2008). Main players in the etiology of this disease are: cariogenic bacteria, fermentable carbohydrates, a susceptible tooth, the host and the time, the relationship of which is described in the following Venn diagram (Richard et al., 2010).

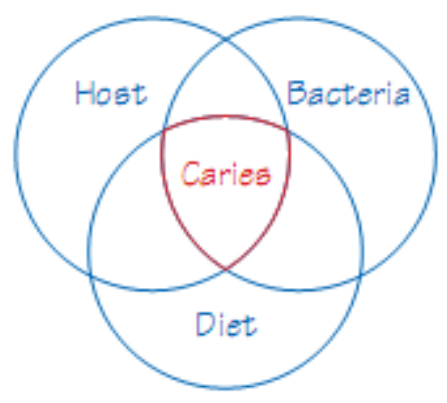

Figure 1. Requirements for caries to occur

Carbohydrates play a very important role in the development of caries. High consumption of carbohydrates (especially sugar and starch) in diet, to fermentation the following sequence:

Starch $\stackrel{\text { hydrolysis }}{\longrightarrow}$ Glucose $\stackrel{\text { glycolysis }}{\longrightarrow}$ Pyruvate $\stackrel{\text { fermentation }}{\longrightarrow}$ Lactic acid 
The environment of mouth is $\mathrm{pH} 7.4$, which is slightly basic. When lactic acid produced the $\mathrm{pHz}$ decreases which increases acidity in the mouth and this will demineralize the tooth leading tooth decay.

\section{The Five Stages of Caries Development:}

Initial subsurface demineralization (reversible lesion), extension of demineralized, zone towards dentine, collapse of surface layer to form cavity (irreversible lesion), extension of caries lesion into dentine and extension of caries into pulp. Streptococcus mutans is the common infectious bacterium that causes biofilm formation followed by fermentation.

\section{Caries:}

Tooth decay (dental caries) is a significant health problem worldwide. It affects not only the vast majority of adults but also children, from $60 \%$ to $90 \%$ of them. In other words, six to nine children in every ten are affected by tooth decay. Repairing and replacing decayed teeth is extremely costly in terms of time and money and is a major drain on the resources of healthcare systems (Sofia et al. 2010).

The tooth surface is covered with a biofilm-a slime layer consisting of millions of bacterial cells, salivary polymers, and food debris. Uncontrolled, this biofilm can easily reach a thickness of hundreds of cells on the surfaces of teeth. The formed biofilm, also called plaque, provides an excellent adhesion site for the colonization and growth of many bacterial species (Marinho et al., 2013). Described in the following diagram (Richard, 2010).

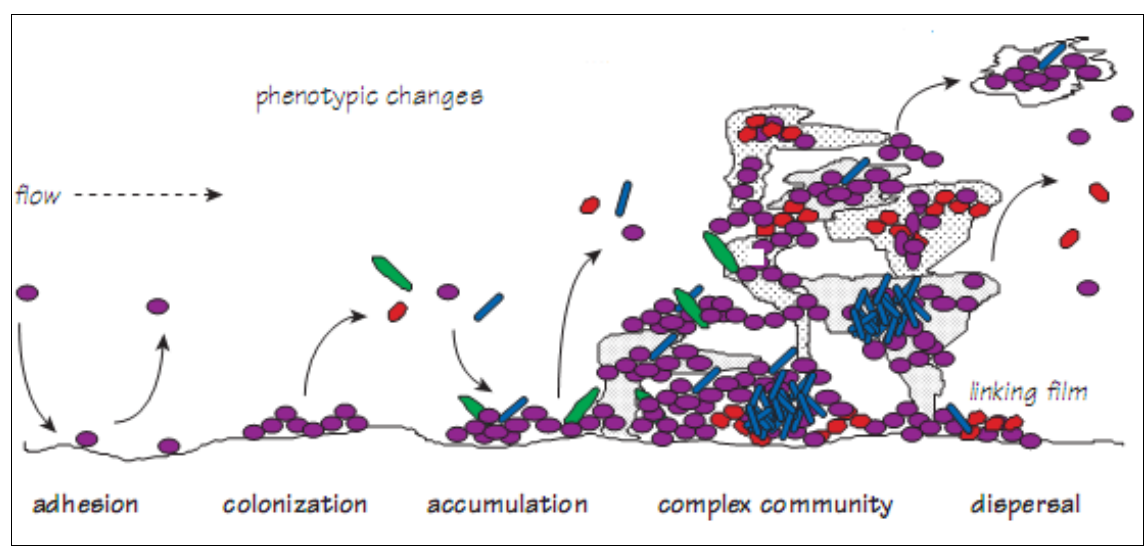

Figure 2. Process of biofilm formation. Reproduced with permission Richard J. Lamont, Howard F. Jenkinson.

$$
\text { Biofilms adhere to stay. Oral Microbiology at a Glance (2010) }
$$

Localized destruction of the tissues of the tooth occurs through bacterial action. Either enamel or cementum is demineralized by microbial acids. The initial caries lesion is sub-surface, due to acid diffusion. The primary lesion that is detectable clinically is known as a white spot and can be reversed by re-mineralization and re-growth of hydroxyapatite crystals, a process enhanced by fluoride. Advanced caries results in cavitations that is irreversible and can progress to the dentin and into the pulp chamber ultimately causing necrosis and periapical abscesses (Lakshman, 2006).

The disease is the most prevalent of the chronic diseases affecting the human race. The original still-prevailing theory explaining the disease process implicates carbohydrates, oral microorganisms, and acids as the main factors in the caries process. Chemico-parasitic process consists of two stages, the decalcification of enamel surface and its total destruction (Selwitz et al., 2007).

Untreated dental caries can affect body weight, growth and quality of life in preschool children (Li, 2002). Caries experience in early childhood has been linked to caries experience in the permanent dentition in several studies (Alm et al., 2007; Skeie et al., 2006; Powell et al., 1998). The burden of dental caries lasts a lifetime be-cause once the tooth structure is destroyed, it will usually require restoration and on-going maintenance throughout life (Tove et al., 2012).

The major factors involved the etiology of caries are host factors (tooth, saliva and diet) and bacteria. 


\section{Host Factors:}

1). Tooth: The structure is important: some areas of the same tooth are much more susceptible to carious attack than others (possibly because of differences in mineral content, especially fluoride), fissure on enamel and space between teeth.

2). Saliva: Mechanical washing action of saliva removes food debris and unattached oral microorganisms. It has a high buffering capacity which tends to neutralize acids produced by plaque bacteria on tooth surfaces, and it is supersaturated with calcium and phosphorus ions, which are important in the remineralization of white-spot lesions. Saliva also acts as a delivery vehicle for fluoride.

Saliva contains proteins such as lactoperoxidase, lypozyme, lactoferrin and immuno-globulin A which can inhibit plaque bacteria (Daniels et al., 1975; Finn et al., 1955; Frank, 1965).

3). Diet: There is a direct relationship between dental caries and the intake of carbohydrates. The most cariogenic sugar is sucrose. Sucrose is highly soluble and diffuses easily into dental plaque. Sucrose is rapidly fermented to acidic end products, but it is also the only dietary carbohydrate that can be transformed into extracellular polysaccharides (EPS) in the plaque. Thus, it is considered to be the most cariogenic carbohydrate in the human diet acting as a substrate for the production of EPS and acids (Sofia et al., 2010).

Cariogenic streptococci produce glucans and other polysaccharides from excess carbohydrate (often sucrose) in the diet, leading to plaque accumulation and production of acids (principally lactic acid), which generate a low $\mathrm{pH}$ environment and suitable for aciduric organisms.

Dental caries cannot occur in the absence of dietary fermentable carbohydrates, and therefore it has been characterized as a "dieto-bacterial" disease (Richard et al., 2010). Since the original observations of Miller, researchers have recognized fermentable carbohydrates as the "fuel" for the caries process, and in the 1940's, (Stephan 1940, 1944), demonstrated the relationship between caries and sugar exposure, leading to the acidification of dental plaque. Moreover, Weiss and Trithart reported a direct relationship between caries experience and the frequency of between-meals consumption of sweet snacks. These findings supported earlier studies by Vipeholm study in Sweden (Gustafsson et al., 1954).

\section{Bacteria:}

Today, S. mutans and Streptococcus sobrinus are considered to be the main etiological microorganisms in caries disease, with lactobacilli and other microorganisms participating in the disease progression. S. mutans and Streptococcus sobrinus are the main cariogenic micro-organisms (Tanzer et al., 2001; Nurelhuda et al., 2010). These acid-producing pathogens inhabiting the mouth cause damage by dissolving tooth structures in the presence of fermentable carbohydrates such as sucrose, fructose, and glucose (Schafer et al., 2000; Caufield \& Griffen, 2000).

Most investigations (Van et al., 1982; Berkowitz et al., 1984; Milnes, 1985) have shown that in children with tooth decay, S. mutans has regularly exceeded $30 \%$ of the cultivable plaque flora. These bacterial masses are often associated with carious lesions, white spot lesions, and sound tooth surfaces near the lesions.

There is relationship between colonization by $S$. mutans and subsequent attack on the teeth to generate white spot (early caries) lesions. Epidemiological studies in humans seek correlations between numbers of $S$. mutans present on teeth and the development of dental caries. Numerous studies suggested a positive correlation, and showed the idea that $S$. mutans levels were a good indicator of active caries, and may indeed be predictive (Richard et al., 2010).

Virulence factors of $S$. mutans are prevalent plaque adhesin-like cell surface proteins, acid tolerance, acid production, and production of glucosyl transferases, mutacin and intracellular polysaccharides. S. mutans ferment many different sugars, and they appear to metabolize sucrose to lactic acid more rapidly than other oral bacteria.

\section{Prevention of Tooth Decay}

Over the years may detailed methods have described the prevention of tooth decay. These multifaceted approaches increase the resistance the dental hard tissues, eliminate or reduce the cariogenic microflora, minimize the availability of microbial diet of sugar especially between meals and changing dietary habits of individuals (avoiding sugar consumption between meals).

Dental caries is a dynamic dieto-microbial disease involving cycles of demineralization and remineralization. The early stages of this process are reversible by modifying or eliminating etiologic factors (such as plaque biofilm and diet) and increasing protective factors (such as fluoride exposure and salivary flow). This approach 
manages dental caries by means of prevention and cure, reserving surgical approaches for those whose disease severity and tissue loss leave no other option (Domenick et al., 2009).

Restriction of sugar consumption is considered a major caries-preventive measure, but the use of fluorides, education and oral hygiene are confounding practices and play more important roles. It has been found that the consumption of sweetened baked goods was significantly related to caries (Anderson et al., 2009).

Dairy products have properties that protect teeth against caries (Harper et al., 1987) and eating cheese after exposure to sugar rapidly neutralizes plaque acidity (Schachtele \& Jensen, 1984) likely because cheese contains calcium phosphate and increases salivary flow.

A wide range of sugar substitutes have low or no cariogenic potential (Zero, 2008). For example, Sucralose is a high-intensity non-cariogenic sweetener (Bowen et al., 1990) and Xylitol has been reported to have anti-cariogenic properties (Burt, 2006). Chewing sugar-containing gum increases caries risk (Burt, 2006), but chewing sugar-free gum after meals can reduce caries risk (Glass, 1981). Some food additives may have protective properties that reduce cariogenicity; for instance, berries can reduce bacterial adherence and glucosyltransferase activity of $S$. mutans (Stookey, 2008), and tea extracts inhibit salivary amylase activity (Koo et al., 2006).

Having the information and skills to make appropriate decisions about a child's diet, hygiene, and fluoride use are essential in order to establish healthy behaviors early in a child's life. Children with caries typically have daily consumption of sugars from liquids (Weinstein et al., 1992; Winter, 1980; Wendt et al., 1991). Caries-promoting sugars such as sucrose, glucose and fructose, contained in fruit juices, (Newbrun, 1982; Grenby et al., 1990; Persson et al., 1985) are readily metabolized by $S$. mutans and lactobacilli to organic acids that demineralize enamel and dentin. The use of nursing bottles and "sippy cups" enhances the frequency of exposure. This type of feeding behavior during sleep intensifies the risk of caries, as oral clearance and salivary flow rate are decreased during sleep (Van, 1981). Parents should be advised to change daily diet habit to reduce or destroy cause of tooth decay.

Children's teeth should be brushed last thing at night, before bedtime and on at least one other occasion. Children should have their teeth brushed with fluoride toothpaste. Eating directly after brushing should be avoided, to prevent fluoride from being washed-out of the mouth prematurely. Fluoride is a mineral that prevents tooth decay. Fluoride is added to the water supply in many areas. It can also be applied directly to teeth in the form of fluoride varnish. This is applied to first (baby) and permanent teeth (depending on the age of the child) usually by a dental professional from two to four times a year. Because it stays on the surface of the tooth for relatively long periods of time it releases fluoride in an efficient and effective way (Marinho et al., 2013).

Flossing can remove plaque from approximal tooth surfaces and may have a role in reducing caries. A combination of brushing with fluoride toothpaste and flossing is more efficient, especially if regular flossing is carried out by an adult. Flossing on its own cannot be recommended for the prevention of dental caries in pre-school children without the associated application of fluoride to the dentition (NCQ).

\section{Conclusion}

In conclusion, tooth decay is one of the significant and costly diseases in the world. Thus, strategies to reduce the risk of dental caries are vital. These strategies usually involve decreasing the growth or activity of bacteria especially $S$. mutans. We should modify daily diet. Parents should advise children to avoid eating between meals especially food containing carbohydrate containing food. Correct method and frequency of brushing should be followed - in the morning and before going to bed and preferably after every major meal. The use of various interdental cleaning aids, such as dental floss, interdental brush (Klock \& Krasse, 1978) should be inculcated. The preventative strategy lies within dietary habits. Therefore, children below certain age must be regularly advised and instructed.

\section{Reference}

Alm, A., Wendt, L. K., Koch, G., \& Birkhed, D. (2007). Prevalence of approximal caries in posterior teeth in 15-year-old Swedish teenagers in relation to their caries experience at 3 years of age. Caries Res., 41, 392-398. http://dx.doi.org/10.1159/000104798

Anderson, C. A., Curzon, M. E. J., Van Loveren, C., Tatsi C., \& Duggal, M. S. (2009). Obesity Department of Paediatric Dentistry, Child Dental Health, Leeds Dental Institute, Reviews, 10(Suppl. 1), 41-54. http://dx.doi.org/ 10.1111/j.1467-789X.2008.00564 
Berkowitz, R. J., Turner, J., \& Hughes, C. (1984). Microbial characteristics of the human dental caries associated with prolonged bottle-feeding. Arch. Oral. Biol., 29, 949-951. http://dx.doi.org/10.1128/JCM.01000-08

Bowen, W, \& Birkhed, D. (1986). Dental caries: dietary and microbiology factors. In L. Granath \& W. D. McHugh (Eds.), Systematized Prevention of Oral Disease: Theory and Practice (pp.19-41). Boca Raton, Fla.: CRC Press.

Bowen, W. H., Young, D. A., \& Pearson, S. K. (1990). The effects of sucralose on coronal and root-surface caries. J. Dent. Res., 69(8), 1485-1487. http://dx.doi.org/10.1177/00220345900690080701

Burt, B. A. (2006). The use of sorbitol- and xylitol-sweetened chewing gum in caries control. JADA, 137(2), 190-196.

Caufield, P. W., \& Griffen, A. L. (2000). Dental caries. An infectious and transmissible disease. Pediatr. Clin. North Am., 47, 1001-1019. http://dx.doi.org/10.1016/S0031-3955(05)70255-8

Daniels, T. S., Silverman, S., Michalski, J. P., Greenspan, J. S., Sylvester, R. A., \& Talal, N. (1975). The oral $\begin{array}{lllll}\text { component of Sjogren's } & \text { syndrome. }\end{array}$ http://dx.doi.org/10.1016/0030-4220(75)90108-5

Dental and Oral Health Problems: Prevention and Services 1-II-233.

Domenick, T. (2009). The Journal of the American Dental Association, 140(1), 25-34.

Finn, S. B., Klapper, C. E., \& Voker, J. F. (1955). Intra-oral effects upon experimentalhamster caries. In R. F. Sognnaes (Ed.), Advances in experimentalcaries research (pp.155-68). Washington, DC: American Association for the Advancement of Sciences.

Frank, R. M., Herdly, J., \& Phillippe, E. (1965). Acquired dental defects and salivary gland lesions after irradiation for carcinoma. J. Am. Dent. Assoc., 70, 868-83.

Glass, R. L. (1981). Effects on dental caries incidence of frequent ingestion of small amounts of sugars and stannous EDTA in chewing gum. Caries Res., 15(3), 256-262. http://dx.doi.org/10.1159/000260522

Grenby, T. H., Mistry, M., \& Desai, T. (1990). Potential dental effects of infants'fruit drinks studied in vitro. $B r$. J. Nutr., 64(1), 273-283. http://dx.doi.org/10.1079/BJN19900028

Gustafsson, B. E., Quensel, C. E., \& Lanke, L. S. (1954). The Vipeholm dental caries study: the effect of different levels of carbohydrate intake on caries activity in 436 individuals observed for five years. Acta. Odontol. Scand., 11(3-4), 232-264. http://dx.doi.org/10.3109/00016355308993925

Harper, D. S., Osborn, J. C., Clayton, R., \& Hefferren, J. J. (1987). Modification of food cariogenicity in rats by mineral-rich concentrates from milk. J. Dent. Res., 66(1), 42-45. http://dx.doi.org/10.1177/00220345870660010901

Klock, B., \& Krasse, B. (1978). Effect of caries preventive measures in children with high numbers of S. mutans and lactobacilli. Scand. J. Dent. Res., 86, 221.

Koo, H., Nino de Guzman, P., Schobel, B. D., Vacca, S. A. V., \& Bowen, W. H. (2006). Influence of cranberry juice on glucan-mediated processes involved in Streptococcus mutans biofilm development. Caries Res., 40(1), 20-27. http://dx.doi.org/ 10.1159/000088901

Lakshman, S. (2006). Essential microbiology for Dental students (pp.267).

Li, Y., \& Wang, W. (2002). Predicting caries in permanent teeth from caries in primary teeth: an eight-year cohort study. J. Dent. Res., 81, 561-566. http://dx.doi.org/10.1177/154405910208100812

Marinho, V. C. C., Worthington, H. V., Walsh, T., \& Clarkson, J. E. (2013). Fluoride varnishes for preventing dental caries in children and adolescents. Cochrane Database of Systematic Review, 7, 279. http://dx.doi.org/10.1002/14651858.CD002279.pub2 .

Milnes, A. R., \& Bowden, G. H. (1985). The microflora associated with developing lesions of nursing caries. Caries Res, 19, 289-297. http://dx.doi.org/10.1159/000260858

National Clinical Guideline (NCQ). (n.d.) Prevention and management of dental decay in the pre-school child. $A$ national clinical guideline, 83, 24.

Newbrun, E. (1982). Sugar and dental caries: a review of human studies. Science, 217(4558), 418-23. http://dx.doi.org/10.1126/science.7046052 
Nurelhuda, N. M., Al-Haroni, M., Trovik, T. A., \& Bakken, V. (2010). Caries experience and quantification of Streptococcus mutans and Streptococcus sobrinus in saliva of Sudanese schoolchildren. Caries Res., 44, 402-407. http://dx.doi.org/10.1159/000316664

Persson, L. A., Holm, A. K., Arvidsson, S., \& Samuelson, G. (1985). Infant feeding and dental caries, a longitudinal study of Swedish children. Swed. Dent. J., 9(5), 201-206.

Powell, L. V. (1998). Caries prediction: a review of the literature. Community Dent. Oral Epidemiol., 26, 361-371. http://dx.doi.org/10.1111/j.1600-0528.1998.tb01974.x

Richard, J. L., Howard, F., \& Jenkinson. (2010a). Oral Microbiology at a Glance (p.7).

Richard, J. L., Howard, F., \& Jenkinson. (2010b). Oral Microbiology at a Glance (p.30).

Richard, J. L., Howard, F., \& Jenkinson. (2010c). Oral Microbiology at a Glance (p.38).

Richard, J. L., Howard, F., \& Jenkinson. (2010d). Oral Microbiology at a Glance (p.37).

Schachtele, C. F., \& Jensen, M. E. (1984). Can foods be ranked according to their cariogenic potential? In H. R. Muhlemann \& B. Guggenheim (Eds.), Cariology Today (pp.136-146). Basel, Switzerland: Karger.

Schafer, T. E., \& Adair, S. M. (2000). Prevention of dental disease. The role of the pediatrician. Pediatr. Clin. North Am., 47, 1021-1042. http://dx.doi.org/10.1016/S0031-3955(05)70256-X

Selwitz, R. H., Ismail, A. I., \& Pitts, N. B. (2007). Dental caries. Lancet, 369, 51-59. http://dx.doi.org/10.1016/S0140-6736(07)60031-2

Skeie, M. S., Raadal, M., Strand, G. V., \& Espelid, I. (2006). The relationship between caries in the primary dentition at 5 years of age and permanent dentition at 10 years of age-a longitudinal study. Int. J. Paediatr. Dent., 16, 152-160. http://dx.doi.org/10.1111/j.1365-263X.2006.00720.x

Sofia, D., Forssten, Marika, B., \& Arthur, C. (2010). Ouwehand. Streptococcus mutans, Caries and Simulation Models Nutrients, 2, 290-298. http://dx.doi.org//10.3390/nu2030290.

Stephan, R. (1940). Changes in hydrogen-ion concentration on tooth surfaces and in carious lesions. JADA, 27(5), 718-723.

Stephan, R. (1944). Intra-oral hydrogen-ion concentrations associated with dental caries activity. J. Dent. Res., 23(4), 257-266. http://dx.doi.org/10.1177/00220345440230040401

Stookey, G. K. (2008). The effect of saliva on dental caries. JADA, 139(5), 11-17. http://dx.doi.org//10.1016/j.tripleo.2008.05.010

Tanzer, J. M., Livingston, J., Thompson, A. M. (2001). The microbiology of primary dental caries in humans. $J$. Dent. Educ., 65, 1028-1037.

Tove, I. W. \& Nina, \& J. W. (2012). Parental influences on dental caries development in preschool children. An overview with emphasis on recent Norwegian research. Norsk Epidemiologi, 22(1), 13-19 http://dx.doi.org// 10.1111/j.1601-5037.2011.00533.x;

Van, H. J. (1981). Experimental odontogenic infections-effects of inoculation methods, dietary carbohydrates, and host age. In J. M. Tanzer (Ed.), Animal models in cariology (special supplement to Microbiology, Abstracts-Bacteriology) (pp.231-238).

Van, H. J., Gibbs, G., \& Butera, C. (1982). Oral flora of children with "nursing bottle caries". J. Dent. Res., 61, 382-385. http://dx.doi.org/10.1177/00220345820610020201

Weinstein, P., Domoto, P., Wohlers, K., \& Koday, M. (1992). Mexican-American parents with children at risk for baby bottle tooth decay: pilot study at a migrant farm workers clinic. ASDC J. Dent. Child, 59(5), 376-383.

Weiss, R. L., \& Trithart, A. H. (1960). Between-meal eating habits and dental caries experience in preschool children. Am. J. Public Health Nations Health, 50(8), 1097-1104. http://dx.doi.org/10.2105/AJPH.50.8.1097

Wendt, L. K, Hallonstein, A. L, \& Koch, G. (1991). Dental caries in one- and two-year-old children living in Sweden. Part I-A longitudinal study. Swed. Dent. J., 15(1), 1-6.

Winter, G. B. (1980). Problems involved with the use of comforters. Int. Dent. J., 30(1), 28-38.

Xhemnica, L., Sulo, D., Rroco, R., \& Hysi, D. (2008). Fluoride varnish application: a new prophylactic method in Albania. Effect on enamel carious lesions in permanent dentition. Paediatric Dent., 9(2), 93-96. 
Zero, D. T. (2008). Are sugar substitutes also anticariogenic? JADA, 139(5), 9-10.

\section{Copyrights}

Copyright for this article is retained by the author(s), with first publication rights granted to the journal.

This is an open-access article distributed under the terms and conditions of the Creative Commons Attribution license (http://creativecommons.org/licenses/by/3.0/). 